\title{
Biological Significance of Protein $N$-Glycosylation and Galectin Lattice Formation
}

\author{
タンパク質の $N$-型糖鎖修飾とガレクチン lattice 形成の生物学的意義
}

\begin{abstract}
Key Words: Protein N-glycosylation, N-acetylglucosaminyltransferase, Galectin lattice, Membrane microdomain, Cell surface residency
\end{abstract}

Elucidating the biological significance of protein $N$ glycosylation has become one of the central topics of postgenome research. The analysis of altered biological properties of proteins bearing mutation(s) at glycosylation site(s), in cells treated with glycosylation inhibitor, or in cells that exhibit overexpression of glycosyltransferase, used to be the only methods to obtain clues to address the issue. These methods revealed that $N$-glycans play pivotal roles in directing normal protein folding, protein quality control, protein sorting, and protein interaction. Recently, extensive studies have revealed the molecular mechanisms underlying the regulation of protein function by $N$-glycans. Over the past decade, mice deficient in $N$-glycan processing enzymes have been engineered and characterized in order to elucidate the in vivo functions of protein $\mathrm{N}$-glycosylation. These studies revealed that the failure of protein $\mathrm{N}$-glycosylation is responsible for many disorders and disease processes and that individual glycosyltransferase enzymes have specific biological functions. $N$ acetylglucosaminyltransferase-IVa (GnT-IVa) and $N$ acetylglucosaminyltransferase-V (GnT-V) are branching enzymes responsible for the formation of multi-antennary complex-type $N$-glycans. GnT-IVa-deficient mice and GnT-V-deficient mice demonstrated abnormalities caused by the decreased levels of cell surface plasmalemmal glycoproteins. These reduced levels are due to impairment of the molecular interactions between $\mathrm{N}$-glycan antennae and endogenous lectins, galectins, on the cell surface, which in turn evokes cellular dysfunction [Ohtsubo, K., et al. (2005) Cell 123, 1307-1321; Demetriou, M., et al. (2001) Nature 409, 733-739; Partridge, E. A., et al. (2004) Science 306, 120-124].

Galectins are a family of lectins that preferentially bind and cross-link $\beta$-galactoside-specific-glycoproteins. The binding avidity depends on the number and the complexity of $\mathrm{N}$-glycans on the protein. The number of $\mathrm{N}$ glycosylation sites is an intrinsic characteristic determined by the primary sequence of each protein, while the complexity of antennae of $\mathrm{N}$-glycans reflects the portfolio of expressed $N$-glycan-processing enzymes and the dynamic supply of metabolites for substrate synthesis [Lau, K., et
タンパク質の $N$-型糖鎖修飾の生物学的意義の解明は, ポ ストゲノム研究の流れの中心に位置している。かつては糖鎖 付加部位への変異の導入や糖鎖合成阻害剂を処理した細胞な らびに, 糖転移酵素の強制発現細胞内のタンパク質の生物学 的性状の変化を解析する事が, 唯一この命題に取り組む術で あった。実際これらの研究により， $N$-型糖鎖修飾が適切なタ ンパク質のフォールディング, 品質管理, ソーティング，相 互作用に打いて重要な役割を担っている事が明らかとなっ た。近年の更なる詳細な解析により, $N$-型糖鎖がタンパク質 の機能を制御する分子メカニズムが詳らかになってきてい る。この十年間に多くの $N$-型糖鎖修飾酵素の欠損マウスが作 成され，その解析により生体内での $N$-型糖鎖修飾の機能解明 が試みられてきた。そしてこれら研究により, タンパク質の $N$-型糖鎖修飾不全が，様々な異常や疾患に関与している事が 見出され, 個々の糖転移酵素が特別な生物学的役割を持つ事 が明らかとなった。 $N$-型糖鎖の分岐構造を合成する酵素であ る $N$-アセチルグルコサミン転移酵素-IVa（GnT-IVa） と-V $(\mathrm{GnT}-\mathrm{V})$ は, 複合型多分岐 $N$-型糖鎖の生合成に不可欠であ る。GnT-IVa 欠損マウスや GnT-V 欠損マウスでは, 細胞表 面上での $N$ - 型糖鎖分岐構造と内在性レクチンであるガレクチ ンとの結合低下が起こり, 細胞表面上の膜タンパク質の residency（定留性）が低下寸る事により細胞機能が障害され， それに起因する様々な異常が生じる[Ohtsubo, K., et al. (2005) Cell 123, 1307-1321; Demetriou, M., et al. (2001) Nature 409, 733-739; Partridge, E. A., et al. (2004) Science 306, 120-124]。

ガレクチンは $\beta$ ガラクトースをもつ糖タンパク質に優先 的に結合し架橋するレクチンである。その結合強度は糖タン パク質上の $N$-型糖鎖の数と分岐の数に依存する。糖タンパク 質上の $N$-型糖鎖修飾部位の数は, それぞれのタンパク質の一 次構造によってコードされる特性である。一方, $N$-型糖鎖の 分岐構造の複雑性は， $N$-型糖鎖修飾酵素の発現抢よび基質合 成への動的代謝産物供給のポートフォリオを反映している 
al. (2007) Cell 129, 123-134]. GnT-I, -II, -IVa/b, and -V initiate the synthesis of $N$-glycan antennae sequentially and cooperatively; following this, $\beta 1$,4-galactosyltransferase forms the Gal $\beta 1-4 \mathrm{GlcNAc}$ structure on each antenna that causes a proportionate increase in their binding affinity to galectins. Therefore, diminished $N$-glycosylation is an outcome of alterations in the cellular micro-environment, which results in the attenuation of galectinglycoprotein binding that might evoke cellular dysfunction.

Although the mechanism underlying the regulation of cell surface expression of glycoproteins has not been fully elucidated, currently available evidences indicate that the galectin-glycoprotein lattice prevents endocytosis and increases cell surface residency of glycoproteins. This mechanism contributes to the appropriate cellular responses to extracellular cognate ligands and to fluctuations in metabolite levels.

Mammary tumor cells derived from polyomavirus middle- $\mathrm{T}$ antigen transgenic mice with GnT-V deficiency show lowered cell surface residency of growth factor receptors coincident with their intracellular accumulation, which is due to the diminished interaction to galectin-3. The reduced cell surface residency of growth factor receptors attenuates the cellular response to the epidermal growth factor, fibroblast growth factor, insulin-like growth factor, platelet-derived growth factor, and transforming growth factor- $\beta$ stimulation. This attenuated growth factor signaling leads to pathological consequences such as reduced in vivo tumor metastasis [Partridge, E. A., et al. (2004) Science 306, 120-124].

Rodent pancreatic $\beta$ cells express glucose transporter-2 (GLUT2) as the glucose sensor on the cell surface and can secrete appropriate amounts of insulin in response to the fluctuating blood glucose level. GnT-IVa produces $N$ glycan antennae on GLUT2 as ligands for galectin-9 in pancreatic $\beta$ cells. The genetic elimination of Mgat $4 a$ (encoding GnT-IVa) or the diminished expression of Mgat $4 a$ induced by high-fat diet administration impair the GLUT2 $N$-glycosylation and galectin-9 binding, which in turn diminishes the $\beta$ cell surface residency of GLUT2 coincident with its accumulation in the endosomes and lysosomes. Genetic mutation at the $\mathrm{N}$-glycosylation site of GLUT1 also results in the severe reduction of cell surface expression accompanied by intracellular accumulation [Asano, T., et al. (1993) FEBS Lett. 324, 258-261]. The structure of the GLUT-family is highly conserved; therefore, these results intensify the importance of the effect of $N$-glycosylation on the cell surface residency of the GLUT family. The severe reduction of $\beta$ cell surface expression of GLUT2 results in the failure of glucose-stimulated insulin
[Lau, K., et al. (2007) Cell 129, 123-134]。GnT-I, -II, -III, $\mathrm{IVa} / \mathrm{b},-\mathrm{V}$ は，連続的にかつ協同的に $N$-型糖鎖の分岐構造の 生合成を担っている。そして, $\beta 1,4$ ガラクトース転移酵素に より Gal $\beta 1-4 \mathrm{GlcNAc}$ 構造がそれぞれの分岐構造上に形成され ると，それに比例してガレクチンとの結合親和性が上昇す る。そのため, 細胞微小環境の変化により引き起こされる $N-$ 型糖鎖修飾の低下が, ガレクチンー糖タンパク質間の結合を減 弱し細胞機能障害を引き起こす。

細胞表面上の糖タンパク質の定留性の制御機構は未だ十 分解明されていないが，ガレクチン-糖タンパク質 lattice 形成 により糖タンパク質のエンドサイトーシスを防ぎ，細胞表面 上での定留性が増す事を示す知見が数多く報告されている。 このメカニズムは, 細胞外からのシグナルや代謝産物レベル の変動に対し，正常に応答する事に寄与している。

GnT-V 欠損/ポリオーマウイルス・ミドル T 抗原トラン スジェニックマウス由来の乳ガン細胞では growth factor 受容 体とガレクチン 3 との結合が減弱し，それにより細胞表面での 受容体の定留性が低下し, 細胞内に貯留する。この細胞表面 での growth factor 受容体の定留性低下により, 上皮増殖因 子, 線維芽細胞増殖因子, インスリン様増殖因子, 血小板由 来増殖因子, トランスフォーミング増殖因子 $\beta$ 刺激による細 胞応答が減弱する。病理学的にはこれら増殖因子のシグナル 伝達の低下が個体内での腫瘍細胞の転移を低下させる事が知 られている [Partridge, E. A., et al. (2004) Science 306, 120$124]$ 。

げっ歯類の膵臓 $\beta$ 細胞は, グルコースセンサー分子とし てグルコーストランスポーター2（GLUT2）を細胞表面に発 現しており，それにより血糖值の変動に応じて適量のインス リン分泌を行うことができる。GnT-IVa は膵蔵 $\beta$ 細胞内で GLUT2 の $N$-型糖鎖修飾を行い, ガレクチン 9 との結合リガ ンドを形成する。GnT-IVaをコードするMgat4a 遺伝子の遺 伝的不活化や高脂肪食負荷による発現低下は, GLUT2 の N型糖鎖修飾, それに引き続くガレクチン 9 との結合を障害す る。その結果, 細胞表面での GLUT2 の定留性が低下し, 工 ンドソームやリソソームへ貯留する。また, GLUT1 の $N$-型 糖鎖付加部位への変異導入が細胞表面での定留性を著しく低 下させ，細胞内に貯留する事も報告されている [Asano, T., et al. (1993) FEBS Lett. 324, 258-261]。GLUT ファミリーの構 造が高度に保存されていることから， $N$-型糖鎖修飾が GLUT ファミリーの細胞表面での定留性に重要である事が強く示唆 される。 $\beta$ 細胞表面上の GLUT2 の発現低下はグルコース刺激 によるインスリン分泌応答不全を引き起こし, それが 2 型糖 
secretion, which evokes type-2 diabetes [Ohtsubo, K., et al. (2005) Cell 123, 1307-1321]. The chromosomal position of the human Mgat4a gene is a susceptible locus for type- 2 diabetes that was identified by the genetic linkage analysis of human type- 2 diabetes patients and their families. The Mgat $4 a$ expression level in pancreatic $\beta$ cells of human type- 2 diabetes patients is significantly reduced. These findings suggest that the GnT-IVa-mediated GLUT2 $\mathrm{N}$-glycosylation is an important link between dietary patterns and the onset of type- 2 diabetes.

Intestinal microvilli (brush border membranes) are cellular membrane protrusions that function as the primary surface of nutrient absorption in the gastrointestinal tract. For this vital function, the microvillar membrane is packed with enzymes that aid in the breakdown of complex nutrients into simpler compounds and transporters for effective absorption. Galectin- 4 is abundant in the "lipid raft" membrane domain of the intestinal microvilli and facilitates the cross-linking of transmembrane aminopeptidase $\mathrm{N}$ and the glycosylphosphatidylinositollinked alkaline phosphatase, so that they can be harbored in the lipid raft domains. Lactose treatment of the lipid raft membrane fraction disrupted the binding of galectin- 4 with the enzymes and released them [Braccia, A., et al. (2003) J. Biol. Chem. 278, 15679-15684]. Although the galectin-4 binding $N$-glycan structure on these enzymes has not been elucidated, proper $N$-glycosylation and the consequential galectin-4 binding are required for the stabilization of the enzymes in the membrane microdomain.

The above-mentioned examples intensify the biological significance of the galectin-glycoprotein lattice on the proper regulation of cellular responses. Organization of plasma membrane structure is a fundamental process that modulates cellular response to micro-environmental signals. Cell surface glycoproteins are compartmentalized or clustered and are embedded in the plasma membrane by lipid-lipid, protein-protein, and lipid-protein interactions, to assemble functional domains for appropriate cellular responses. Multiple $\mathrm{N}$-glycosylation and formation of multi-antennary $\mathrm{N}$-glycan structures on proteins increase their affinity for endogenous lectins, galectins. Furthermore, oligomerized galectins are multivalent and have high affinity to glycan ligands on proteins. The constructed galectin- $N$-glycan lattice contributes to the organization of functional glycoprotein assembly on the cell surface; this paradigm can be practically applied to better understand the true nature of biological systems in general.
尿病を誘発する [Ohtsubo, K., et al. (2005) Cell 123，13071321]。2 型糖尿病患者々その家族の遺伝子連鎖解析から， ヒ 卜 Mgat $4 a$ 遺伝子が 2 型糖尿病感受性遺伝子領域に存在する事 が明らかになって抢り, 加えて, ヒト 2 型糖尿病患者膵蔵 $\beta$ 細胞内で Mgat4a 遺伝子の発現が非常に低下している事から， GnT-IVa による GLUT2 の $N$-型糖鎖修飾が食環境と 2 型糖尿 病発症とをつなぐ重要な鍵であることが示唆される。

腸微絨毛（刷子縁膜）は細胞膜の突起構造であり，消化 管に抢ける主要な栄養吸収を担っている。この重要な役割を 果たすため, 微絨毛には栄養素複合体を単純な分子へと分解 するための酵素や, 効率よく吸収するための輸送体が集中し ている。ガレクチン 4 は腸微絨毛の lipid raft 膜ドメインに豊 富に存在し，膜型アミノペプチダーゼ $\mathrm{N}$ や GPI 結合型アルカ リフォスファターゼを架橋結合する。それにより，これら酵 素を lipid raft 膜ドメインに停めて扔く事ができる。事実，こ の lipid raft 膜画分をラクトースで処理する事により，ガレク チン 4 とこれら酵素との結合を破壊すると，これら分子が溶 出されてくる事が示されている [Braccia, A., et al. (2003) J. Biol. Chem. 278, 15679-15684]。ガレクチン 4 が結合している これら酵素上の $N$-型糖鎖構造は明らかになっていないが，適 切な $N$-型糖鎖修飾とそれによるガレクチン 4 との結合が，膜 マイクロドメイン上でこれら酵素を安定させるのに必要なの である。

上記の例は適切な細胞応答を行う上で，ガレクチンー糖タ ンパク質 lattice が非常に重要である事を強く示唆している。 膜構造の組織化は微小環境シグナルへの細胞応答を調節する 不可欠な過程である。細胞膜表面の糖タンパク質は区分化, クラスター化され, 脂質一脂質, 脂質ータンパク質, タンパク 質一タンパク質相互作用により膜に埋め込まれた形で存在し， 適切な細胞応答のための機能ドメインを構築している。タン パク質上の複数の $N$-型糖鎖修飾や多分岐構造の形成は，ガレ クチンなどの内在性レクチンとの結合を強める。更に, オリ ゴマー化したガレクチンはタンパク質の糖鎖リガンドに対し 多価の高結合活性を持つ。したがって，「細胞表面上でのガレ クチン $-N$-型糖鎖 lattice による, 機能性糖タンパク質複合体 の組織化」という概念は一般的生物システムの実態をより理 解するのに役立つと考えられる。 
Reported by: Kazuaki Ohtsubo

Department of Disease Glycomics

The Institute of Scientific and Industrial Research,

Osaka university

Room 262, 8-1 Mihogaoka, Ibaraki, Osaka 567-0047

Voice \& Fax: + 81-6-6879-4142 (or 8413)

e-mail:kohtsubo@sanken.osaka-u.ac.jp
大坪和明

大阪大学産業科学研究所疾患糖鎖学寄附研究部門 